OPEN ACCESS

Edited by:

Xiangli Tian,

Ocean University of China, China

Reviewed by:

Nor Azman Kasan,

University of Malaysia Terengganu,

Malaysia

Nicholas Romano,

University of Arkansas at Pine Bluff,

United States

*Correspondence:

Paul B. Brown

pb@purdue.edu

Specialty section:

This article was submitted to

Marine Fisheries, Aquaculture

and Living Resources,

a section of the journal

Frontiers in Marine Science

Received: 29 November 2021

Accepted: 02 February 2022

Published: 24 February 2022

Citation:

Chu Y-T and Brown PB (2022)

Optimal Dietary Crude Protein

in Commercial Feeds for Shrimp and Halophytes in Marine Aquaponic

Biofloc Systems.

Front. Mar. Sci. 9:824973.

doi: 10.3389/fmars.2022.824973

\section{Optimal Dietary Crude Protein in Commercial Feeds for Shrimp and Halophytes in Marine Aquaponic Biofloc Systems}

\author{
Yu-Ting Chu and Paul B. Brown* \\ Department of Forestry and Natural Resources, Purdue University, West Lafayette, IN, United States
}

Formulated diets for animals is the primary source of nutrients in aquaponic systems that need to maintain beneficial bacteria as well as for plants. Dietary protein is one of the expensive macronutrients in fish diets, especially when fishmeal is used, and it is the source of nitrogen $(\mathrm{N})$ for other biotic components. Biofloc has the potential to serve as the supplement diet for shrimp and reduce the need of expensive protein. However, it is not clear if low dietary protein will be adequate to support the three organisms (animals, plants, and bacteria) in an aquaponic system operated with biofloc technology. The aim of the present study was to investigate the effect of shrimp feed with different protein concentrations $(30,35$, or $40 \%)$ on water quality and the growth performance of Pacific whiteleg shrimp (Litopenaeus vannamei) and three edible halophytic plants (Atriplex hortensis, Salsola komarovii, and Plantago coronopus) in biofloc-based marine aquaponics. The experiment was conducted for 12 weeks, the plants were harvested and seedlings transplanted every 4 weeks. Dietary protein content did not influence shrimp growth in the current study, indicating that feeds with lower protein concentrations can be used in biofloc-based marine aquaponic systems. During the early and mid-stages of cultivation, plants grew better when supplied diets with higher protein concentration, whereas no differences were observed for later harvests. Hence, for maximum production with mature systems or in the scenario of high concentration of nitrate, providing a higher protein concentration feed in the early stages of system start-up, and switching to a lower protein concentration feed in later stages of cultivation was recommended.

Keywords: marine aquaponics, crude protein concentration, nutrient management, Litopenaeus vannamei, halophytic plants, biofloc, sustainable food production

\section{INTRODUCTION}

The primary source of nutrients into aquaponic systems is the feed for the animal. Bacteria and plants then rely on waste excretions from the animal, solubilization of nutrients from uneaten feed and feces, and/or conversion of nutrients by bacteria as their primary nutrient sources. Among the macronutrients, protein is the main source of nitrogen $(\mathrm{N})$. Dietary crude protein and the constituent essential amino acids are vital for the growth and health of animals and waste $\mathrm{N}$ is 
excreted primarily as ammonia- $\mathrm{N}\left(\mathrm{NH}_{3}\right)$ across the gills of aquatic animals. Excreted $\mathrm{NH}_{3}$ can be metabolized by bacterial colonies within the system to nitrite- $\mathrm{N}\left(\mathrm{NO}_{2}{ }^{-}\right)$and nitrate- $\mathrm{N}$ $\left(\mathrm{NO}_{3}{ }^{-}\right)$, which plants use as their $\mathrm{N}$ source. Several aspects of nutrient input into aquaponic systems have been evaluated, such as feeding frequency, feeding regime, feed amount to plant area ratio, animal to plant ratio, water retention time, and subsystem ratio (Rakocy, 2012; Liang and Chien, 2013; Lam et al., 2015; Yang and Kim, 2019, 2020a; Chu and Brown, 2021a). However, the effects of the dietary protein concentration on aquaponics have not been fully evaluated.

Meeting the nutritional needs of target crops is vital for successful operation. Insufficient dietary crude protein concentrations will result in reduced growth of animals, lower $\mathrm{NH}_{3}$ excretion and potentially inadequate concentrations of $\mathrm{NO}_{2}{ }^{-}$and $\mathrm{NO}_{3}{ }^{-}$for plants. However, an excessive concentration of dietary crude protein could result in the accumulation of toxic nitrogen compounds. Dietary protein in aquatic animal diets is generally considered one of the macronutrients that influence the price of feeds; thus, the complex $\mathrm{N}$ flow through aquaponic subsystems is a significant economic consideration. One of the basic tenets in nutrition is quantification of the minimum concentration of nutrient that results in maximum response. This fundamental concept has not been fully explored in integrated systems where both animal and plant nutrition is important.

Pacific whiteleg shrimp (Litopenaeus vannamei) are the largest crustacean aquaculture industry globally (FAO, 2020), can potentially produce 3-4 marketable crops per year, display high market demand and value, are tolerant of a wide range of salinities and stocking densities (FAO, 2016; Gao et al., 2016; Ross et al., 2017; Araneda et al., 2020) and may alleviate the "economic drain" associated with fish raised in freshwater aquaponic systems (Quagrainie et al., 2018). The optimal dietary crude protein concentration for shrimp varies as a function of several factors, and one of them that influence protein requirement is biofloc. It is generally considered to be in the range of $25-45 \%$ of the diet (Xu et al., 2012; Xu and Pan, 2014; Yun et al., 2016; Lee and Lee, 2018; Panigrahi et al., 2019). The three plant crops (Atriplex hortensis, Salsola komarovii, and Plantago coronopus) we have been working with have high nutrient concentrations (Carlsson and Clarke, 1983; Zhao and Feng, 2001; Koyro, 2006) and have been successfully grown in marine aquaponics with Pacific whiteleg shrimp (Chu and Brown, 2021a,b).

Biofloc technology (BFT) is one of the sustainable approaches used in high-density aquaculture to manage water quality, especially for shrimp farming (Avnimelech, 1999, 2006; Browdy et al., 2012). The BFT system deviated from the strictly recirculating culture systems by relying on heterotrophic bacteria to help degrade waste products instead of attempting to maintain nearly pure cultures of chemolithotrophs. Additional organic carbon input is commonly required to maintain healthy heterotrophic populations (Crab, 2010; Browdy et al., 2012; Crab et al., 2012; Xu et al., 2016). Ecosystem services provided by these diverse microbial communities include the recycling of waste material and nutrient supply to the target crop (Avnimelech, 1999; Crab, 2010; Browdy et al., 2012; Crab et al., 2012). Several reports indicated lower concentrations of dietary crude protein did not significantly affect shrimp growth in biofloc systems (Xu et al., 2012; Yun et al., 2016). However, it is not clear if low dietary crude protein will be adequate in an aquaponic system operated with biofloc technology.

The objective of this study was evaluation of varying concentrations of dietary crude protein in practical diets fed to shrimp raised in biofloc aquaponic saltwater systems.

\section{MATERIALS AND METHODS}

\section{Aquaponic System Design}

Nine experimental systems were designed, constructed, and used in this research. Systems were located at the Aquaculture Research Lab (ARL), Purdue University, West Lafayette, IN,

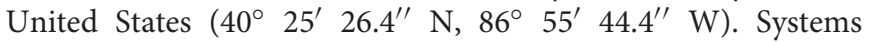
were described previously (Chu and Brown, 2021b). Briefly, each aquaponic system had $113.6 \mathrm{~L}$ aquaculture tank, a $102.2 \mathrm{~L}$ hydroponic tank, and an 18.9 L biofilter tank. Air stones were placed in every aquaculture, hydroponic and biofilter tank. Water temperature was maintained within the range of $26-28^{\circ} \mathrm{C}$ using submersible heaters (300w; Aqueon, WI, United States). The airlift system moved water at a rate of $3 \mathrm{~L} / \mathrm{min}$. LED lights (40w, 5,000 lumens, 4,000K daylight white; Kihung LED, Guangdong, China) were suspended at a height of 6.5 inches over the plant growth bed. Photosynthetic photon flux density (PPFD) was determined by a quantum sensor (MQ-500 FullSpectrum Quantum Meter; Apogee Instruments, Inc., Logan, UT, United States). The photosynthetically active radiation (PAR) averaged $239 \mu$ molm $^{-2} \mathrm{~s}^{-1}$. The photoperiod during the experiment was set as $14 \mathrm{~h}$ light (6:00 am-8:00 pm) and $10 \mathrm{~h}$ dark (8:00 pm-6:00 am).

\section{Biological Material Shrimp}

Juvenile Pacific whiteleg shrimp (Litopenaeus vannamei) were transported from a private producer (RDM Aquaculture, Fowler, IN, United States) to the ARL in water of $24^{\circ} \mathrm{C}$ and salinity of 15 ppt. Shrimp were separated into three $700 \mathrm{~L}$ tanks and quarantined for a week before moving into experimental units. Shrimp were fed twice a day (8:00 a.m. and 5:00 p.m.) with commercial shrimp feed (Zeigler Brothers, Gardners, PA, United States) during quarantine. Daily feeding amount was 3.0\% of total biomass, divided into aliquots.

\section{Plants}

Seeds of three halophytic plants, red orache (Atriplex hortensis), okahijiki (Salsola komarovii), and minutina (Plantago cornonpus), were obtained from a commercial source (Johnny's Selected Seeds, Winslow, ME, United States). Seeds were sowed in horticubes, soilless foam medium (OASIS Grower Solutions, Kent, $\mathrm{OH}$, United States), and irrigated with fresh water for a week while germinating. Beginning the 2 nd week, sea salt (Instant Ocean, Blacksburg, VA, United States) was added to increase the salinity in the irrigation water at a rate of 2-3 ppt every 2 days to a final salinity of $15 \mathrm{ppt}$. 


\section{Experimental Design and System Management}

The experiment was conducted for 12 weeks (October 17, 2020 to January 9, 2021). Growth assay of shrimp and the three halophytes was determined as a function of three different commercial diets containing 30\% (P30), 35\% (P35), or $40 \%$ (P40) crude protein (Supplementary Figure 1). Specific ingredients concentrations were proprietary, but all three diets are commercially available. One week prior to the experiment, shrimp were weighed and placed in aquaculture tanks to produce nutrients for plants. The stocking density of shrimp was 300 shrimp $/ \mathrm{m}^{2}$ (60 shrimp/tank, $\left.600 \mathrm{shrimp} / \mathrm{m}^{3}\right)$, with an initial average weight of $1.46 \mathrm{~g}$. A total of 24 plants ( 8 plants per species) were stocked in each hydroponic tank, which was equivalent to a density of 100 plants $/ \mathrm{m}^{2}$. Shrimp were fed three times per day at 8:00 a.m., 1:00 p.m., and 6:00 p.m., with a total daily amount of $3.0 \%$ of bodyweight divided into aliquots. Plants were harvested every 4 weeks and new seedlings were transplanted.

Initial water in all experimental systems remained from prior experiments. In the interim between experiments, evaporative losses were replaced with well water, constant aeration was provided to all subsystems and probiotics (EZ-Bio, Bacillus spp., Zeigler Brothers, Gardners, PA, United States) were added weekly at a dose of $10 \mathrm{ppm}$ EZ-bio once a week. Once shrimp moved into experimental units, additional doses of probiotics were added every other day in the 1st week, twice per week in the 2nd week, and once per week beginning in the 3rd week continuing until the end of the experiment (Crab et al., 2010; Chu, 2014; Chu and Brown, 2021b). Molasses (Hawthorne Gardening Co., Vancouver, WA, United States) was provided as an organic carbon source for the adjustment of $\mathrm{C} / \mathrm{N}$ ratio. The amount of molasses added was based on the $\mathrm{C} / \mathrm{N}$ content of shrimp feed and the carbon content of the molasses to raise the $\mathrm{C} / \mathrm{N}$ ratio to 15 (Table 1). If alkalinity decreased below $75 \mathrm{mg} / \mathrm{L}$, or $\mathrm{pH}$ lower than 7.2 , potassium bicarbonate was added to adjust environmental conditions. If $\mathrm{pH}$ rose above $8.0,10 \%$ sulfuric acid was applied.

The nine aquaponic systems used for this experiment were each randomly assigned to one of three treatments $(n=3)$. Throughout the 12-week experiment, no water was discharged or exchanged, only added to replace evaporative losses.

\section{Measurement of Water Quality}

Dissolved oxygen (DO) and temperature (OxyGuard Handy Polaris DO meter, Farum, Denmark), pH (pHTestr 10 Pocket

TABLE 1 | The amount of molasses needed to get $\mathrm{C} / \mathrm{N}$ ratio to 15 for the three commercial shrimp feed.

\begin{tabular}{lcccc}
\hline Product & $\begin{array}{c}\text { Protein } \\
\text { content (\%) }\end{array}$ & $\begin{array}{c}\text { Total } \\
\text { carbon (\%) }\end{array}$ & C/N ratio & $\begin{array}{c}\text { Amount of } \\
\text { molasses needed } \\
\text { (g/g feed) }\end{array}$ \\
\hline SI-30 & 30 & 42.1 & 8.7 & 0.85 \\
HI-35 & 35 & 41.8 & 7.1 & 1.2 \\
PL-40 & 40 & 42.0 & 6.9 & 1.5 \\
Molasses & - & 35.0 & - & - \\
\hline
\end{tabular}

$\mathrm{pH}$ Tester, Vernon Hills, IL, United States) were measured and recorded in each system twice daily at 8:00 a.m. and 6:00 p.m. before feeding. Salinity (Vital Sine Salinity Refractometer, Pentair Aquatic Eosystems, Apopka, FL, United States) was determined once per day at 8 a.m. Water samples were collected twice weekly from aquaculture tanks before feeding, to determine the concentrations of total ammonia-nitrogen (TAN), nitrite- $\mathrm{N}\left(\mathrm{NO}_{2}{ }^{-}\right)$, nitrate- $\mathrm{N}\left(\mathrm{NO}_{3}{ }^{-}\right)$, phosphate $\left(\mathrm{PO}_{4}{ }^{3-}\right)$, and alkalinity. TAN, $\mathrm{NO}_{2}{ }^{-}, \mathrm{NO}_{3}{ }^{-}$, and $\mathrm{PO}_{4}{ }^{3-}$ were measured using Hach methods 8155, 8507, 8039, and 8048, respectively, using a Hach DR3900 spectrophotometer $(\mathrm{HACH}$, Loveland, CO, United States). Alkalinity was determined with Hach kit (HACH, Loveland, CO, United States). Total suspended solids (TSS) and volatile suspended solids (VSS) were measured once weekly following United States EPA method 1684.

\section{Growth Performance \\ Shrimp}

Weights and numbers of shrimp were collected at the beginning and end of the experiment. Feed input was recorded every day and summed. The following formulae were used to calculate shrimp responses:

$$
\begin{aligned}
& \text { Survival (\%) }=\frac{\text { Final number of shrimp }}{\text { Initial number of shrimp }} \times 100 \text {; } \\
& \text { Weight gain }(\%)=\frac{\begin{array}{l}
\text { (Final biomass }(\mathrm{g})- \\
\text { Initial biomass }(\mathrm{g}))
\end{array}}{\text { Initial biomass }} \times 100 \text {; and } \\
& \text { Specific growth rate }(\%)=\frac{[\text { Ln (Final biomass }(\mathrm{g}))-}{\text { dayitial biomass }(\mathrm{g}))]} \times 100 .
\end{aligned}
$$

\section{Plants}

Edible parts of all plants were collected and weighed individually at the beginning and end of the experiment. Plant samples were dried in an oven at $100^{\circ} \mathrm{C}$ until constant weight and then measured as dry weight. In addition, dried plant samples were ground and filtered through a 10-mesh sieve and stored in plastic vials for nutrient analysis. Plant tissue analysis was done by the Midwest laboratory (Omaha, NE, United States). Formula used to calculate plant growth indices and nitrogen use efficiency were:

$$
\begin{aligned}
& \text { [Ln (Final biomass (g)) - } \\
& \text { Relative growth rate }(\%)=\frac{\operatorname{Ln}(\text { Initial biomass }(\mathrm{g}))]}{\text { day }} \times 100 \text {; } \\
& \text { (Final fresh weight }(\mathrm{g})- \\
& \text { Water content }(\%)=\frac{\text { Final dry weight }(\mathrm{g}))}{\text { Final fresh weight }} \times 100 \text {; and, }
\end{aligned}
$$


Nitrogen use efficiency (NUE) $=\frac{\mathrm{g} \mathrm{N} \text { absorbed }}{\mathrm{g} \mathrm{N} \text { supplied }} \times 100$.

\section{Statistical Analysis}

Shrimp and plant responses, nutrient concentrations in plants, and water quality parameters were subjected to analysis of variance (ANOVA) using JMP Pro 16.0 (SAS Institute Inc., Cary, NC, United States). Interactions between treatment and plant species or harvest time were tested by two-way ANOVA. Statistical difference between means were determined by Tukey's honestly significant difference test (HSD) at $p \leq 0.05$.

\section{RESULTS}

\section{Shrimp Response}

There were no significant differences in final weight, weight gain (WG), or specific growth rate (SGR) of shrimp among dietary treatments (Table 2). Shrimp mortality increased in the last 2 weeks of the experiment (Figure 1), and most carcasses were soft-shelled and had traces of being eaten. The average survival of P30, P35, and P40 treatments was 72.8, 66.1 , and $49.4 \%$, respectively (Table 2 ). To alleviate shrimp mortality and the increasing TAN, feeding was reduced to $1 / 3$ of the original amount from week 10 until the end of the experiment.

\section{Plant Response}

Plant growth parameters of all three plants were significantly $(p<0.05)$ affected by harvest time. Only okahijiki was also affected by dietary crude protein concentration and the interaction of dietary crude protein and harvest time (Figure 2). In general, dietary crude protein concentrations significantly $(p<0.05)$ affected the growth performance of red orache and okahijiki in the first and second harvest, while there were no significant $(p>0.05)$ differences among treatments in the third harvest. Red orache and okahijiki had better final fresh weight and final dry weight in the P35 treatment in the first two harvests. In the third harvest, although there was no difference among treatments, red orache had relatively better performance in P40 than other treatments, whereas, okahijiki still

TABLE 2 | Growth parameters and survival of Litopenaeus vannamei fed with three levels of dietary protein in marine aquaponics for 12 weeks.

\begin{tabular}{lccrc}
\hline Parameter & \multicolumn{4}{c}{ Treatment } \\
\cline { 2 - 5 } & P30 & P35 & P40 & P \\
\hline Initial weight (g) & $1.46 \pm 0.01$ & $1.45 \pm 0.01$ & $1.46 \pm 0.01$ & ns \\
Final weight (g) & $9.41 \pm 0.68$ & $9.46 \pm 1.21$ & $10.41 \pm 0.73$ & ns \\
WG (\%) & $546.7 \pm 47.1$ & $551.8 \pm 83.9$ & $615.0 \pm 51.2$ & ns \\
SGR (\%) & $2.22 \pm 0.09$ & $2.22 \pm 0.15$ & $2.34 \pm 0.09$ & ns \\
Survival (\%) & $72.8 \pm 2.5$ & $66.1 \pm 5.4$ & $49.4 \pm 20.2$ & ns
\end{tabular}

Each value represents means $\pm S D$.

ns means no significant at $p>0.05$. performed better in the P35 treatment. The growth performance of minutina was increased with the increasing protein level, yet there were no significant $(p>0.05)$ differences among treatments. The growth of the three plants was significantly $(p<0.05)$ increased with harvest time (Figure 2$)$. Red orache and minutina's fresh weight and dry weight were 1.5 to twofold greater in the second and third harvests, and okahijiki's fresh weight and dry weight were 2-3 times as great as the first harvest.

The interaction of plant species and treatment exerted no significant effect on yield, NUE, or the concentration of $\mathrm{N}, \mathrm{P}$, and $\mathrm{K}$ (Table 3). However, the yield, and the concentrations of $\mathrm{N}, \mathrm{P}$, and $\mathrm{K}$ were significantly $(p<0.05)$ affected by plant species, and NUE was significantly $(p<0.05)$ affected by plant species, and treatment. The production of each plant species was not significantly $(p>0.05)$ different among treatments. When comparing the three plant species in each treatment, the yield and NUE of okahijiki was significantly lower $(p<0.05)$ than that of red orache and minutina regardless of protein level; however, okahijiki contained the highest concentrations of N, P, and $\mathrm{K}$ in tissues. NUE declined with increasing crude protein concentration, and the lowest NUE of all three plant species was in the P40 treatment.

\section{Water Quality}

During the 12-week experiment, temperature and dissolved oxygen (DO) were maintained at $26-28^{\circ} \mathrm{C}$ and $6.4-7.1 \mathrm{mg} / \mathrm{L}$ in all treatments, respectively. The salinity was monitored and controlled every day to maintain at $15 \mathrm{ppt}$. There were no significant differences $(p>0.05)$ in alkalinity, TSS, VSS, or environmental $\mathrm{pH}$ among treatments (Figure 3 and Table 4). The $\mathrm{pH}$ in the three treatments decreased over time, but the decrease was consistent across all treatment (Figure 3).

The concentrations of TAN, nitrite-N, nitrate-N, and phosphate are shown in Figure 4. The concentration of TAN and nitrite-N slightly increased after every harvest (day 28 and day 56), but remained below 0.9 and $0.4 \mathrm{ppm}$, respectively (Figures 4A,B). However, the concentration of TAN increased to around $2 \mathrm{ppm}$ in P35 and P40 treatments, and $1.5 \mathrm{ppm}$ in P30 treatment on day 73 (Figure 4A). The concentration of nitrite- $\mathrm{N}$ in the P35 and P40 treatments was higher than that in P30 treatment after day 35 (Figure 4B). Similar to TAN and nitrite-N, the concentration of nitrate$\mathrm{N}$ was higher in the higher protein treatment. However, nitrate- $\mathrm{N}$ concentrations decreased over time in all three treatments (Figure 4C). Unlike the fluctuation in nitrogenous compounds, the concentration of phosphate steadily increased over time (Figure 4D).

\section{DISCUSSION}

\section{Shrimp Growth}

Based on these data, dietary crude protein concentrations higher than $30 \%$ do not appear to confer additional benefit to whiteleg shrimp grown in aquaponic systems with biofloc. Lower dietary crude protein concentrations commonly results in lower costs 


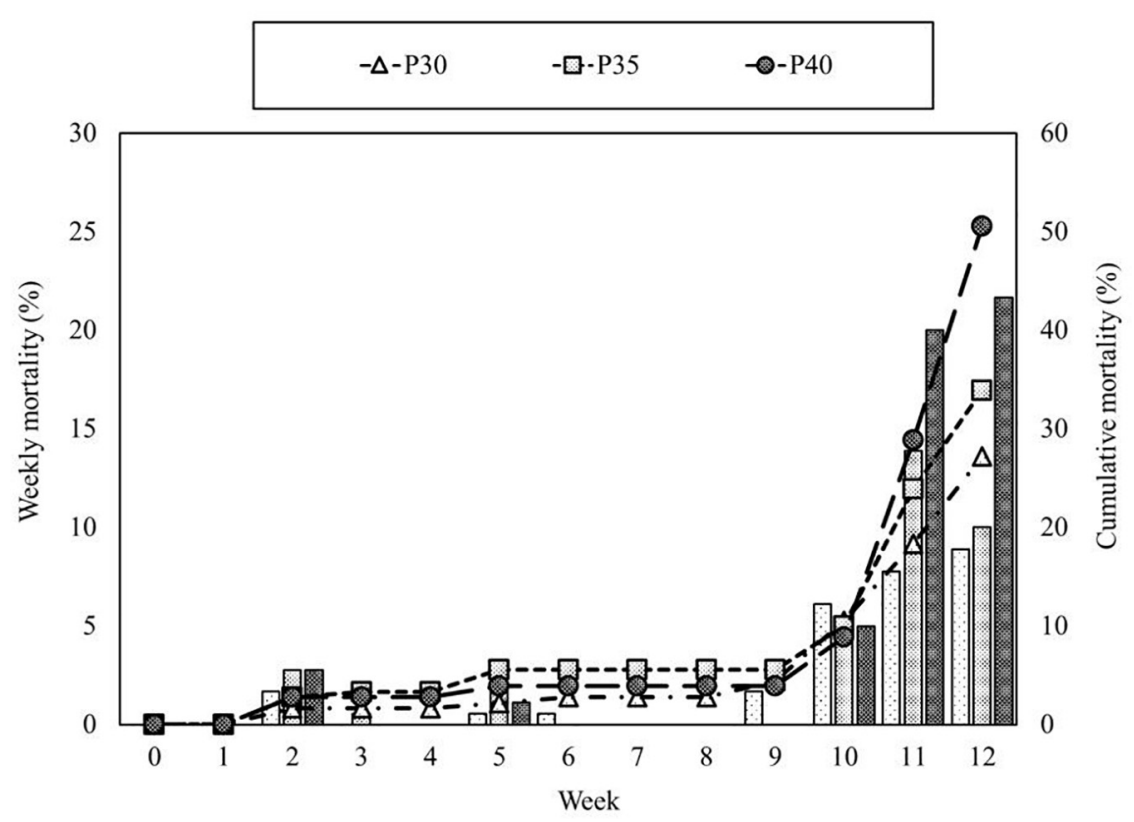

FIGURE 1 | Weekly (bar) and cumulative mortality (line) of Litopenaeus vannamei fed with three levels of dietary protein in marine aquaponics for 12 weeks.

diets. If there is no benefit feeding higher concentrations of crude protein, this potentially results in improved economic efficiency. Several studies have demonstrated that shrimp experience better growth performance and lower FCR when fed higher protein diets (Xia et al., 2010; Shahkar et al., 2014; Jana et al., 2021); however, daily exchanges of water occurred in these studies. In contrast, other researchers reported that there is the possibility of reducing dietary crude protein concentration in shrimp feed without affecting growth performance when BFT is applied (Xu et al., 2012; Panigrahi et al., 2019). The present study also implemented BFT and showed similar results to previous research. These results could be attributed to the microbial proteins, which serve as a source of supplemental protein for shrimp in this kind of system (Ballester et al., 2010; Browdy et al., 2012).

The high mortality rate that occurred at the late stage of the present study might be related to competition for space, cannibalism, $\mathrm{pH}$ decrease, insufficient ions, or increased nitrogenous compounds (Abdussamad and Thampy, 1994; Wheatly, 1999; Nga et al., 2005; Arnold et al., 2006). In crustaceans, molting is associated with growth, and they are vulnerable at postmolt, which has been viewed as a period conducive to disease and dysfunction (Lemos and Weissman, 2021). In the postmolt period, the new cuticle is predominantly mineralized with external calcium. Furthermore, Zanotto and Wheatly (1995) reported that the uptake of calcium by shrimp was reduced by $60 \%$ under low $\mathrm{pH}$ conditions. Insufficient calcium in the water or a low $\mathrm{pH}$ can retard the calcification of the cuticle and delay recovery from molting, leading to mortality and cannibalism (Zanotto and Wheatly, 1993; Wheatly, 1999). In the present study, $\mathrm{pH}$ decreased with time, which might have contributed to low Ca uptake and soft-shelled shrimp, along with high mortality in the later stage of cultivation. Additionally, shrimp without a hard shell are subject to attacks from fellow shrimp, and toxic substances (TAN or nitrite-N) are also more likely to penetrate the membrane into the body and cause poisoning and death (Lemos and Weissman, 2021). This might be an explanation for the relatively lower survival in higher protein treatments. More research is needed to investigate the feeding and calcium management, and determine the optimal $\mathrm{pH}$ range for shrimpbased aquaponics.

\section{Plants}

Similar to the results with shrimp, there were no significant benefits of feeding higher dietary crude protein concentrations to yield and NUE of plants. The goal of food production systems is to optimize nutrient use efficiency in order to increase production yields while reducing inputs (USDA, 2007). In the present study, plants provided with $40 \%$ dietary crude protein did not return with higher growth and yield but resulted in low NUE, which suggested excessive $\mathrm{N}$ was provided. Yield was numerically higher in systems offered 35\% dietary crude protein. More importantly, yield increased over time.

Nutrient requirements for optimal growth of plants varies by species, growth stage, temperature, $\mathrm{pH}$, and other environmental factors (Hawkesford et al., 2011; Abbasi et al., 2017; Prieto et al., $2017)$. The yield of all three plant species increased significantly $(p<0.05)$ with each harvest (Figure 2), which was similar to the result published by Yang and Kim (2020b). They suggested the increased production was related to the maturity of the system. Furthermore, the ratio of $\mathrm{NH}_{4}{ }^{+}$to $\mathrm{NO}_{3}{ }^{-}$and $\mathrm{pH}$ decrease in the present study might also play a role in this result. Plants grow better when provided a mixed supply of 


\section{$\square$ 1st Harvest $\quad \square$ 2nd Harvest $\mathbf{0}$ 3rd Harvest}
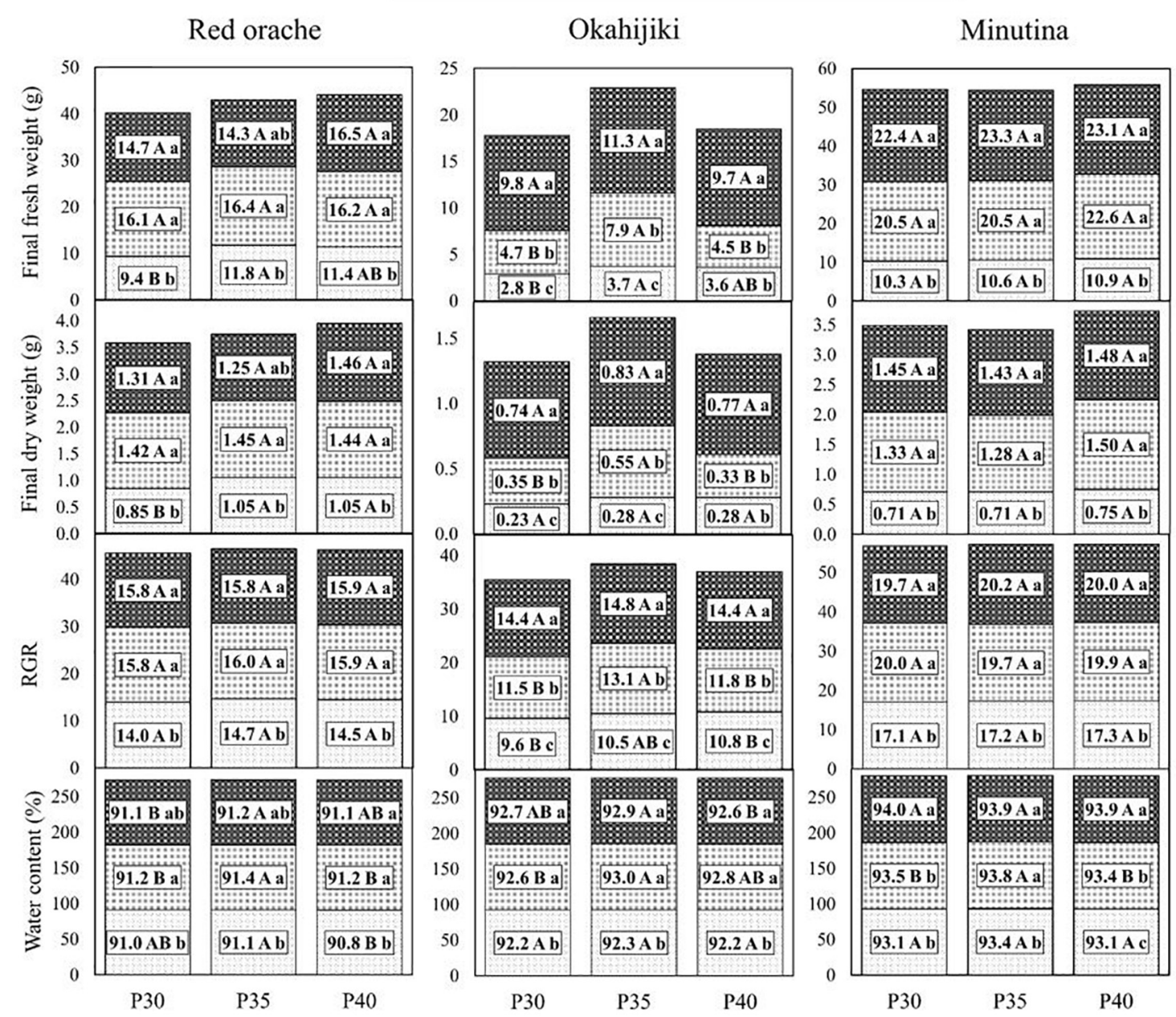

Treatment

\begin{tabular}{lccc}
\hline ANOVA & Red orache & Okahijiki & Minutina \\
\hline Treatment & ns & $* * *$ & $\mathrm{~ns}$ \\
Harvest time & $* * *$ & $* * *$ & $* * *$ \\
Treatment $\times$ Harvest time & $\mathrm{ns}$ & $*$ & $\mathrm{~ns}$ \\
\hline
\end{tabular}

FIGURE 2 | Plant growth parameters of red orache, okahijiki, and minutina at three harvest times. Each value represents means. Values within rows followed by different uppercase alphabet letters indicate significant differences $(p<0.05)$ between treatments. Values within columns with different lowercase alphabet letters indicate significant differences $(p<0.05)$ between harvest times. ns, ${ }^{*}$, *** means no significant or significant at $p \leq 0.05$, or 0.0001 , respectively.

$\mathrm{NH}_{4}{ }^{+}$and $\mathrm{NO}_{3}{ }^{-}$, while the optimal ratio varies from species to species, common ratio of $\mathrm{NH}_{4}{ }^{+}: \mathrm{NO}_{3}{ }^{-}$are 1:9, 1:3, or 1:1 (Hawkesford et al., 2011; Zhang et al., 2019; Yang et al., 2020; Zhu et al., 2021). At the early stage of the present study, the concentration of $\mathrm{NO}_{3}^{-}$(>10 ppm) was relatively higher than that of TAN $(<0.5 \mathrm{ppm})$ and was the main source of $\mathrm{N}$ for plants in the water. This could be the potential reason for lower growth at the early stage, because $\mathrm{NO}_{3}{ }^{-}$assimilation consumes more energy than ammonium assimilation. Before plant assimilation, $\mathrm{NO}_{3}{ }^{-}$has to be reduced to nitrite and then ammonium by nitrate reductase and nitrite reductase, respectively (Hawkesford et al., 2011). The concentration of TAN slowly increased over time, whereas that of nitrate- $\mathrm{N}$ presented in an opposite trend (Figures $\mathbf{4 A}, \mathbf{C}$ ), which resulted in a mixed nutrient in the middle and late stages of the cultivation, and this could contribute to the improvement of plant growth in 
TABLE 3 | Average nutrient content, yield, and nitrogen use efficiency (NUE) of red orache, okahijiki, and minutina from the three harvests.

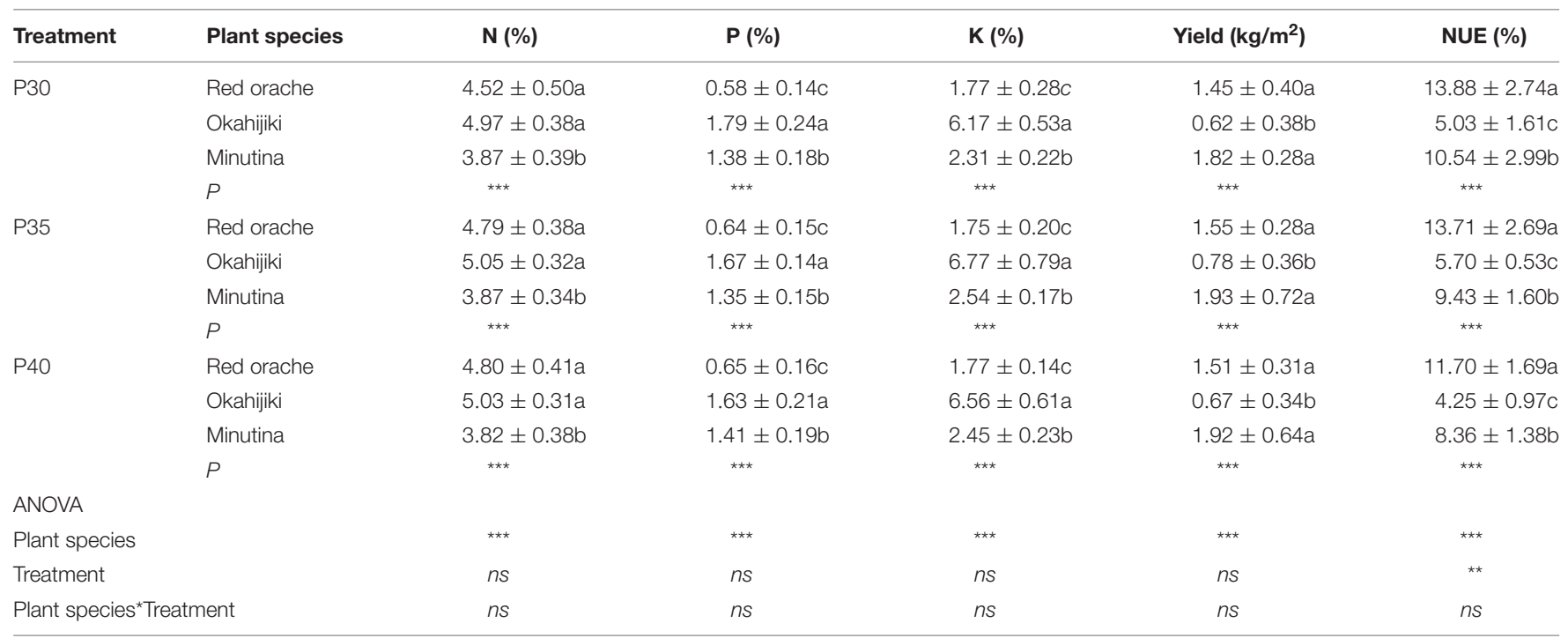

Each value represents means $\pm S D$. Values in same columns of each treatment with different lowercase alphabet letters are significantly different ( $p<0.05)$. $n s,{ }^{* *},{ }^{* * *}$ mean no significant or significant at $p \leq 0.01$, or 0.001 , respectively.

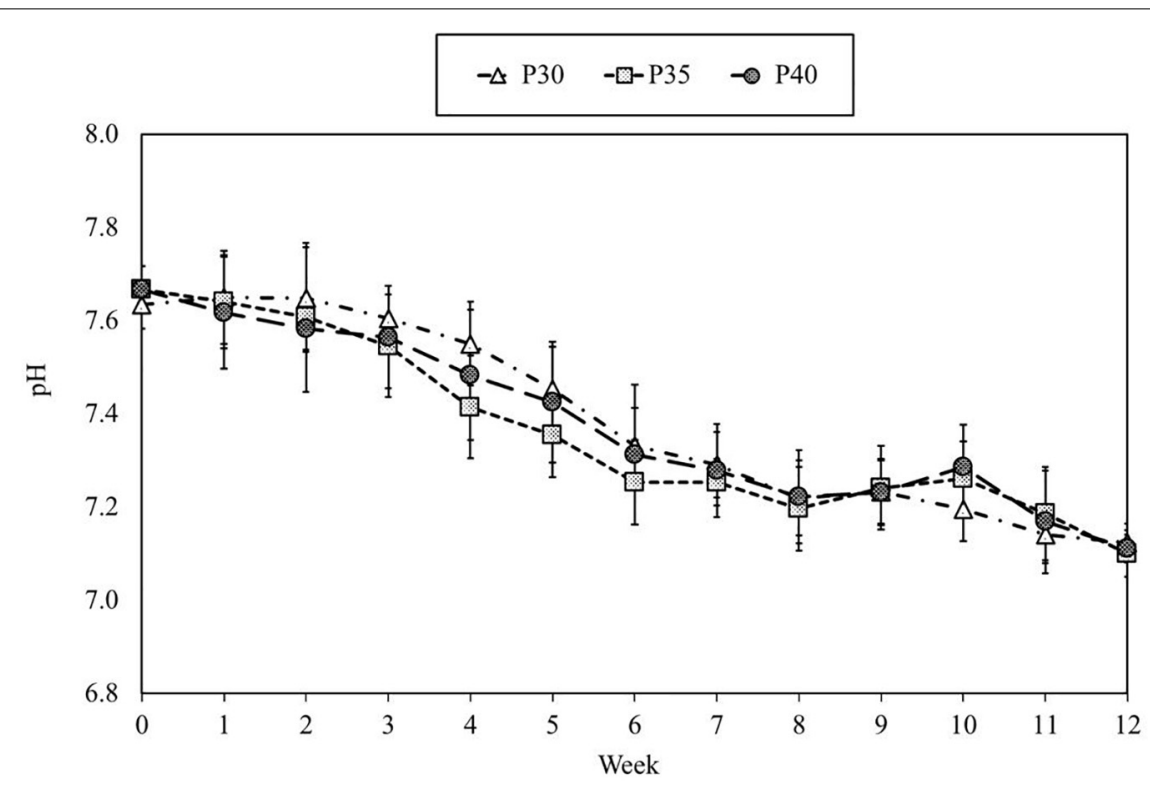

FIGURE 3 | Dynamic of $\mathrm{pH}$ in marine aquaponics provided with varying concentrations of protein feeds for 12 weeks. Each point represents the means ( \pm SD) of three replicates in each treatment.

TABLE 4 | Average concentrations of water-quality parameters (range) in marine aquaponics provided with varying concentrations of protein feeds for 12 weeks.

\begin{tabular}{|c|c|c|c|c|c|}
\hline Treatment & Temperature $\left({ }^{\circ} \mathrm{C}\right)$ & DO (mg/L) & Alkalinity (mg/L) & TSS (mg/L) & VSS (mg/L) \\
\hline P30 & (26.9-28.0) & $(6.4-7.1)$ & $(73-120)$ & $(22.2-63.7)$ & $(12.7-42.8)$ \\
\hline P35 & $(27.0-27.8)$ & $(6.4-7.1)$ & $(67-133)$ & (26.3-66.3) & $(15.0-43.0)$ \\
\hline \multirow[t]{2}{*}{ P40 } & $27.4 \pm 0.2$ & $6.8 \pm 0.2$ & $104.5 \pm 22.3$ & $55.0 \pm 22.7$ & $33.8 \pm 16.0$ \\
\hline & (27.0-27.8) & $(6.4-7.1)$ & $(73-140)$ & (28.0-105.9) & $(14.8-67.2)$ \\
\hline
\end{tabular}

Each value represents means $\pm S D$ (range). 


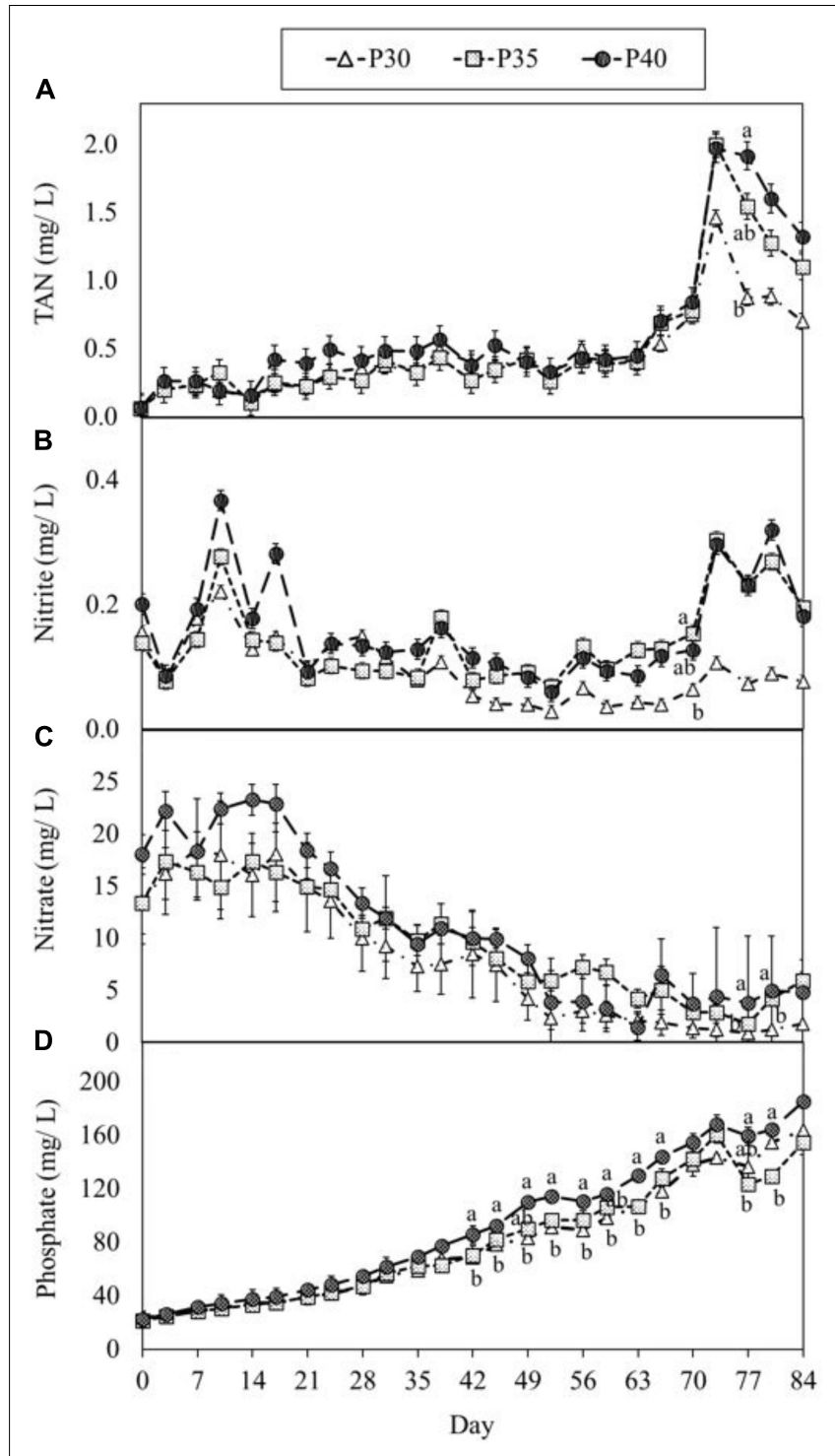

FIGURE 4 | The change of TAN (A), nitrite (B), nitrate (C), and phosphate (D), concentrations in marine aquaponics provided with varying concentration of protein feeds for 12 weeks. Values are means $( \pm S D)$ of three replicates. Lower-Case alphabet letters represent significant differences, followed by one way ANOVA and Turkey's HSD test $(\alpha=0.05)$.

the last two harvests. In addition, the availability of nutrient elements is higher when $\mathrm{pH}$ is lower (Somerville et al., 2014; Goddek et al., 2019). Therefore, the better growth performance and production of the three plants in the second and third harvest might be explained by the mixed factors mentioned above. More research is needed on successive harvests from aquaponic systems.

Plank and Kissel (1989) reported the critical concentrations of $\mathrm{N}, \mathrm{P}$, and $\mathrm{K}$ in plant tissue are $2.75,0.3$, and $2.0 \%$, respectively. The result of the plant tissue analysis (Table 3 ) indicated the concentrations of $\mathrm{N}, \mathrm{P}$, and $\mathrm{K}$ were above those values, and indicated that the plants were not N, P or K limited.
Stoyanova et al. (2019) reported that higher protein content in fish feed was related to a higher concentration of nitrogenous compounds and phosphate in the water and contributed to better production of lettuce. In general, the growth performance of the three plants in the present study were higher in P35 and P40 treatments than those grown in P30 treatment (Figure 2). This result aligned with their findings.

\section{Water Quality}

The concentration of TAN remained below 0.9 ppm until day 70 , while nitrite- $\mathrm{N}$ remained below $0.4 \mathrm{ppm}$ the during the course of this experiment; however, $\mathrm{pH}$ decreased. The change in $\mathrm{pH}$ is likely due to increasing biomass, increasing feed input and increased $\mathrm{CO}_{2}$ excretion. The decreased $\mathrm{pH}$ affects the activity of nitrifying bacteria and further impacts the process of nitrification (Jadhav et al., 2010; Satapute et al., 2012). In general, optimal $\mathrm{pH}$ range for ammonia-oxidizing bacteria (AOB) is 7.0-8.0, and optimal $\mathrm{pH}$ for nitrite-oxidizing bacteria (NOB) is 7.5-8.0. Because of these phenomena, the concentration of TAN and $\mathrm{NO}_{2}{ }^{-}$increased at the late stage of cultivation. In addition, the efficiency of calcium absorption and utilization by shrimp decreases with decreasing $\mathrm{pH}$ and likely contributed to the mortality in this study.

In the present study, the concentrations of toxic substances (TAN and nitrite-N) remained at acceptable ranges for shrimp culture, and this could be attributed to the use of probiotics and introducing mature water and bio-media from a stable system. This result aligned with the findings reported by other researchers (Otoshi et al., 2011; Xu and Pan, 2012; Cerozi and Fitzsimmons, 2016; Chu and Brown, 2021a,b). TAN can be stabilized and remain below $0.1 \mathrm{mg} / \mathrm{L}$ within 3 weeks in new systems via inoculating probiotics on a regular basis (Cerozi and Fitzsimmons, 2016; Chu and Brown, 2021b). $\mathrm{Xu}$ and Pan (2012) demonstrated that the concentrations of TAN and $\mathrm{NO}_{2}{ }^{-}$remained under $0.51 \mathrm{ppm}$ and $1.25 \mathrm{mg} / \mathrm{L}$, respectively, by introducing biofloc from an established system prior to the experiment. Chu and Brown (2021a) reused the water and bio-media from previous experiment, and the toxic compounds, TAN and $\mathrm{NO}_{2}{ }^{-}$, remained below $0.2 \mathrm{ppm}$ the entire research period.

Steadily increased nitrate- $\mathrm{N}$ is commonly occurred in matured aquaponics and has been reported by other researchers (Nozzi et al., 2016; Boxman et al., 2017, 2018; Yang and Kim, 2019; Pinheiro et al., 2020). However, the concentration of nitrate- $\mathrm{N}$ in the present study decreased with experiment time. The potential factor for this phenomena was the dominance of heterotrophic bacteria (HB) in the water, which facilitated by the inoculation of probiotics and additional organic carbon (Xu and Pan, 2012; Cerozi and Fitzsimmons, 2016; Chu and Brown, 2021a,b). The dominance of $\mathrm{HB}$ hinders the growth of $\mathrm{AOB}$ and $\mathrm{NOB}$ and affects the process of nitrification (Zhu and Chen, 2001; Michaud et al., 2006). Along with the absorption by plants, this can explain the steady decrease of $\mathrm{NO}_{3}{ }^{-}$in the present study. More research is needed to investigate environmental $\mathrm{pH}$, and the effect of applying commercial probiotics.

Among the research in aquaponics, some researchers reported low concentrations of $\mathrm{PO}_{4}{ }^{3-}$, about $1-17 \mathrm{mg} / \mathrm{L}$ in the systems 
(Seawright et al., 1998; Al-Hafedh et al., 2008; Endut et al., 2010; Huang et al., 2021). However, in the present study, the concentration of $\mathrm{PO}_{4}{ }^{3-}$ accumulated with the experiment time, which aligned with other studies, and this can be attributed to several factors, including heterotrophic bacteria dominated in biofloc results in fewer algae present to absorb $\mathrm{P}$ (Xu et al., 2016), the presence of $\mathrm{Na}$ and $\mathrm{Cl}$ impacts $\mathrm{P}$ assimilation (Nozzi et al., 2016), and daily $\mathrm{P}$ provided from aquafeed exceeds plant's ability to assimilate (Yang and Kim, 2020a). Due to its scarcity and finite supply, phosphorus is an expensive component in hydroponic solutions (Hawkesford et al., 2011; Goddek et al., 2015). Between 30 and $85 \%$ of the dietary P input ends up as uneaten feed, fish excretion, and feces, which is the primary source of environmental contamination ( $\mathrm{Wu}$, 1995; Seawright et al., 1998; Schneider et al., 2005). Therefore, growing plants with aquaculture effluent could address the issues in both aquaculture and hydroponics. However, the accumulation of $\mathrm{PO}_{4}{ }^{3-}$ needs to be addressed, both from an environmental viewpoint as well as the potential ability to produce more plant crops.

\section{CONCLUSION}

Among the findings of the present study, it was found that shrimp growth was not affected by the protein content of the feed, suggesting that it is possible to use feeds with lower protein concentration when culturing shrimp in bioflocbased marine aquaponics. However, plants grew better in the treatments with higher protein content feed in the early and middle stages of the operation. Hence, for a longer period of shrimp cultivation, providing a higher protein content feed (35\%) until the middle stage and switching to a lower protein content feed $(30 \%)$ at the late stage of cultivation might be feasible. Yet, more research is needed to study the feeding scheme in biofloc-based marine aquaponics to provide better guidelines for managing water quality for successful operation and better production.

\section{REFERENCES}

Abbasi, H. N., Vasileva, V., and Lu, X. (2017). The influence of the ratio of nitrate to ammonium nitrogen on nitrogen removal in the economical growth of vegetation in hybrid constructed wetlands. Environments 4:24. doi: 10.3390/ environments 4010024

Abdussamad, E. M., and Thampy, D. M. (1994). Cannibalism in the tiger shrimp Penaeus monodon Fabricius in nursery rearing phase. J. Aquacult. Trop. 9, 67-75. doi: 10.1111/j.1749-7345.1994.tb00189.x

Al-Hafedh, Y. S., Alam, A., and Beltagi, M. S. (2008). Food production and water conservation in a recirculating aquaponic system in Saudi Arabia at different ratios of fish feed to plants. J. World Aquac. Soc. 39, 510-520. doi: 10.1111/j. 1749-7345.2008.00181.x

Araneda, M., Gasca-Leyva, E., Vela, M. A., and Domínguez-May, R. (2020). Effects of temperature and stocking density on intensive culture of Pacific white shrimp in freshwater. J. Therm. Biol. 94:102756. doi: 10.1016/j.jtherbio.2020.102756

Arnold, S. J., Sellars, M. J., Crocos, P. J., and Coman, G. J. (2006). An evaluation of stocking density on the intensive production of juvenile brown tiger shrimp (Penaeus esculentus). Aquaculture 256, 174-179. doi: 10.1016/j.aquaculture. 2006.01.032

\section{DATA AVAILABILITY STATEMENT}

The original contributions presented in the study are included in the article/Supplementary Material, further inquiries can be directed to the corresponding author.

\section{AUTHOR CONTRIBUTIONS}

Y-TC: conceptualization, methodology, investigation, validation, formal analysis, data curation, writing-original draft preparation, and editing. PB: resources, supervision, project administration, funding acquisition, and writing - review and editing. Both authors have read and agreed to the published version of the manuscript.

\section{FUNDING}

Funding for this project was provided by the Purdue University Department of Forestry and Natural Resources, the College of Agriculture, and the United States Department of Agriculture. Publication of this article was funded in part by Purdue University Libraries Open Access Publishing Fund.

\section{ACKNOWLEDGMENTS}

We would like to thank Zeigler Bros., Inc., for their donation of commercial shrimp feed and EZ-bio. We also would like to thank Robert Rode, Aquaculture Research Lab for his help and support for the study.

\section{SUPPLEMENTARY MATERIAL}

The Supplementary Material for this article can be found online at: https://www.frontiersin.org/articles/10.3389/fmars. 2022.824973/full\#supplementary-material

Avnimelech, Y. (1999). Carbon/Nitrogen ratio as a control element in aquaculture systems. Aquaculture 176, 227-235. doi: 10.1016/S0044-8486(99)00085-X

Avnimelech, Y. (2006). Bio-filters: the need for an new comprehensive approach. Aquac. Eng. 34, 172-178. doi: 10.1016/j.aquaeng.2005.04.001

Ballester, E. L. C., Abreu, P. C., Cavalli, R. O., Emerenciano, M., de Abreu, L., and Wasielesky, W. (2010). Effect of practical diets with different protein levels on the performance of Farfantepenaeus paulensis juveniles nursed in a zero exchange suspended microbial flocs intensive system. Aquac. Nutr. 16, 163-172. doi: 10.1111/j.1365-2095.2009.00648.x

Boxman, S. E., Nystrom, M., Capodice, J. C., Ergas, S. J., Main, K. L., and Trotz, M. A. (2017). Effect of support medium, hydraulic loading rate and plant density on water quality and growth of halophytes in marine aquaponic systems. Aquac. Res. 48, 2463-2477. doi: 10.1111/are.13083

Boxman, S. E., Nystrom, M., Ergas, S. J., Main, K. L., and Trotz, M. A. (2018). Evaluation of water treatment capacity, nutrient cycling, and biomass production in a marine aquaponic system. Ecol. Eng. 120, 299-310. doi: 10. 1016/j.ecoleng.2018.06.003

Browdy, C. L., Ray, A. J., Leffler, J. W., and Avnimelech, Y. (2012). "Biofloc-based aquaculture systems," in Aquaculture Production Systems, ed. J. Tidwell (Oxford, UK: Johy Wiley \& Sons, Inc.), 278-307. doi: 10.1002/9781118250105.ch12 
Carlsson, R., and Clarke, E. M. W. (1983). Atriplex hortensis L. as a leafy vegetable, and as a leaf protein concentrate plant. Qual. Plant. Plant Foods Hum. Nutr. 33, 127-133. doi: 10.1007/bf01091298

Cerozi, B. D. S., and Fitzsimmons, K. (2016). Use of Bacillus spp. to enhance phosphorus availability and serve as a plant growth promoter in aquaponics systems. Sci. Hortic. 211, 277-282. doi: 10.1016/j.scienta.2016.09.005

Chu, Y. T. (2014). Effects of Different Probiotics on Water Qualities and Growth in Close Culture System of Litpenaeus vannamei. Keelung: National Taiwan Ocean University. [PhD thesis].

Chu, Y. T., and Brown, P. B. (2021a). Evaluation of Pacific whiteleg shrimp and three halophytic plants in marine aquaponic systems under three salinities. Sustainability 13:269. doi: 10.3390/su13010269

Chu, Y. T., and Brown, P. B. (2021b). Sustainable marine aquaponics: effects of shrimp to plant ratio and C/N ratios. Front. Mar. Sci. 8:771630. doi: 10.3389/ fmars.2021.771630

Crab, R. (2010). Bioflocs Technology: an Integrated System for the Removal of Nutrients and Simultaneous Production of Feed in Aquaculture.[PhD thesis]. Ghent: Ghent University.

Crab, R., Chielens, B., Wille, M., Bossier, P., and Verstraete, W. (2010). The effect of different carbon sources on the nutritional value of bioflocs, a feed for Macrobrachium rosenbergii postlarvae. Aquac. Res. 41, 559-567. doi: 10.1111/ j.1365-2109.2009.02353.x

Crab, R., Defoirdt, T., Bossier, P., and Verstraete, W. (2012). Biofloc technology in aquaculture: beneficial effects and future challenges. Aquaculture 35, 351-356. doi: 10.1016/j.aquaculture.2012.04.046

Endut, A., Jusoh, A., Ali, N., Wan Nik, W. B., and Hassan, A. (2010). A study on the optimal hydraulic loading rate and plant ratios in recirculation aquaponic system. Bioresour. Technol. 101, 1511-1517. doi: 10.1016/j.biortech.2009.09.040

FAO (2016). The State of World Fisheries and Aquaculture 2016. Contributing to Food Security and Nutrition for All. Rome: FAO.

FAO (2020). The State of World Fisheries and Aquaculture 2020. Sustainability in Action. Rome: FAO.

Gao, W., Tian, L., Huang, T., Yao, M., Hu, W., and Xu, Q. (2016). Effect of salinity on the growth performance, osmolarity and metabolism-related gene expression in white shrimp Litopenaeus vannamei. Aquac. Rep. 4, 125-129. doi: 10.1016/j.aqrep.2016.09.001

Goddek, S., Delaide, B., Mankasingh, U., Ragnarsdottir, K. V., Jijakli, H., and Thorarinsdottir, R. (2015). Challenges of sustainable and commercial aquaponics. Sustainability 7, 4199-4224. doi: 10.3390/su7044199

Goddek, S., Joyce, A., Kotzen, B., and Butnell, G. M. (2019). Aquaponics Food Production Systems, 1st Edn. Denmark: Cham Springer.

Hawkesford, M., Horst, W., Kichey, T., Lambers, H., Schjoerring, J., Møller, I. S., et al. (2011). "Functions of Macronutrients," in Marschner's Mineral Nutrition of Higher Plants (Ed)M. Horst, (Amsterdam: Elsevier Ltd), 135-189. doi: 10.1016/ B978-0-12-384905-2.00006-6

Huang, C. C., Lu, H. L., Chang, Y. H., and Hsu, T. H. (2021). Evaluation of the water quality and farming growth benefits of an intelligence aquaponics system. Sustainability 13:4210. doi: 10.3390/su13084210

Jadhav, G. G., Salunkhe, D. S., Nerkar, D. P., and Bhadekar, R. K. (2010). Isolation and characterization of salt-tolerant nitrogen-fixing microorganisms from food. Eur. Asian J. Biosci. 4, 33-40. doi: 10.5053/ejobios.2010.4.0.5

Jana, P., Prasad Sahu, N., Sardar, P., Shamna, N., Varghese, T., Dharmendra Deo, A., et al. (2021). Dietary protein requirement of white shrimp, Penaeus vannamei (Boone, 1931) juveniles, reared in inland ground water of medium salinity. Aquac. Res. 52, 2501-2517. doi: 10.1111/are.15100

Koyro, H. W. (2006). Effect of salinity on growth, photosynthesis, water relations and solute composition of the potential cash crop halophyte Plantago coronopus (L.). Environ. Exp. Bot. 56, 136-146. doi: 10.1016/j.envexpbot.2005. 02.001

Lam, S. S., Ma, N. L., Jusoh, A., and Ambak, M. A. (2015). Biological nutrient removal by recirculating aquaponic system: optimization of the dimension ratio between the hydroponic \& rearing tank components. Int. Biodeterior. Biodegrad. 102, 107-115. doi: 10.1016/j.ibiod.2015.03.012

Lee, C., and Lee, K. J. (2018). Dietary protein requirement of Pacific white shrimp Litopenaeus vannamei in three different growth stages. Fish. Aquat. Sci. 21:30. doi: 10.1186/s41240-018-0105-0

Lemos, D., and Weissman, D. (2021). Moulting in the grow-out of farmed shrimp: a review. Rev. Aquac. 13, 5-17. doi: 10.1111/raq.12461
Liang, J. Y., and Chien, Y. H. (2013). Effects of feeding frequency and photoperiod on water quality and crop production in a tilapia-water spinach raft aquaponics system. Int. Biodeterior. Biodegrad. 85, 693-700. doi: 10.1016/j.ibiod.2013.03. 029

Michaud, L., Blancheton, J. P., Bruni, V., and Piedrahita, R. (2006). Effect of particulate organic carbon on heterotrophic bacterial populations and nitrification efficiency in biological filters. Aquac. Eng. 34, 224-233. doi: 10. 1016/j.aquaeng.2005.07.005

Nga, B. T., Lürling, M., Peeters, E. T. H. M., Roijackers, R., Scheffer, M., and Nghia, T. T. (2005). Chemical and physical effects of crowding on growth and survival of Penaeus monodon Fabricius post-larvae. Aquaculture 246, 455-465. doi: 10.1016/j.aquaculture.2005.02.026

Nozzi, V., Parisi, G., Di Crescenzo, D., Giordano, M., and Carnevali, O. (2016). Evaluation of Dicentrarchus labrax meats and the vegetable quality of Beta vulgaris var. Cicla farmed in freshwater and saltwater aquaponic systems. Water 8:423. doi: 10.3390/w8100423

Otoshi, C. A., Rodriguez, N., and Moss, S. M. (2011). Establishing nitrifying bacteria in super-intensive biofloc shrimp production. Glob. Aquac. Advocate 14, 24-26.

Panigrahi, A., Sundaram, M., Saranya, C., Satish Kumar, R., Syama Dayal, J., Saraswathy, R., et al. (2019). Influence of differential protein levels of feed on production performance and immune response of pacific white leg shrimp in a biofloc-based system. Aquaculture 503, 118-127. doi: 10.1016/j.aquaculture. 2018.12.036

Pinheiro, I., Carneiro, R. F. S., Vieira, F., do, N., Gonzaga, L. V., Fett, R., et al. (2020). Aquaponic production of Sarcocornia ambigua and Pacific white shrimp in biofloc system at different salinities. Aquaculture 519:734918. doi: 10.1016/j. aquaculture.2019.734918

Plank, C. O., and Kissel, D. E. (1989). Plant Analysis Handbook for Georgia. [PhD thesis]. Georgia: University of Georgia College of Agricultural Extension Service.

Prieto, K. R., Echaide-Aquino, F., Huerta-Robles, A., Valério, H. P., MacedoRaygoza, G., Prado, F. M., et al. (2017). "Endophytic bacteria and rare earth element; promising candidates for nutrient use efficiency in plants," in Plant Macronutrient Use Efficiency, eds M. A. Hossain, T. Kamiya, D. J. Burritt, L.-S. P. Tran, and T. Fujiwara (Cambridge: Academic Press), 285-306. doi: 10.1081/e-ess3-120015983

Quagrainie, K. K., Flores, R. M. V., Kim, H. J., and McClain, V. (2018). Economic analysis of aquaponics and hydroponics production in the U.S. Midwest. J. Appl. Aquac. 30, 1-14. doi: 10.1080/10454438.2017.1414009

Rakocy, J. E. (2012). “Aquaponics - Integrating fish and plant culture," in Aquaculture Production Systems, ed. J. Tidwell (Oxford, UK: Johy Wiley \& Sons, Inc.), 343-386. doi: 10.1002/9781118250105.ch14

Ross, W., Gallaudet, R. T., and Oliver, C. (2017). Fisheries of the United States, 2017. U.S. Department of Commerce, NOAA Current Fishery Statistics No. 2017. Available online at: https://www.fisheries.noaa.gov/feature-story/ fisheries-united-states-2017. (accessed on Feb 04, 2022).

Satapute, P., Shetti, A., Kulkarni, A. G., and Hiremath, G. (2012). Isolation and characterization of nitrogen fixing Bacillus subtilis strain as- 4 from agricultural soil AS-4 from agricultural soil. Int. J. Recent Sci. Res. 3, 762-765.

Schneider, O., Sereti, V., Eding, E. H., and Verreth, J. A. J. (2005). Analysis of nutrient flows in integrated intensive aquaculture systems. Aquac. Eng. 32, 379-401. doi: 10.1016/j.aquaeng.2004.09.001

Seawright, D. E., Stickney, R. R., and Walker, R. B. (1998). Nutrient dynamics in integrated aquaculture-hydroponics systems. Aquaculture 160, 215-237. doi: 10.1016/S0044-8486(97)00168-3

Shahkar, E., Yun, H., Park, G., Jang, I. K., Kyoung Kim, S., Katya, K., et al. (2014). Evaluation of optimum dietary protein level for juvenile whiteleg shrimp (Litopenaeus vannamei). J. Crustac. Biol. 34, 552-558. doi: 10.1163/1937240X00002267

Somerville, C., Cohen, M., Pantanella, E., Stankus, A., and Lovatelli, A. (2014). Small-Scale Aquaponic Food Production. Integrated Fish and Plant Farming. FAO Fisheries and Aquaculture Technical Paper No. 589. Rome: FAO.

Stoyanova, S., Sirakov, I., Velichkova, K., and Ali, M. (2019). Effect of feed protein level on water chemical and technological parameters of a recirculating aquaponics system for carp (Cyprinus carpio L.) and lettuce (Lactuca sativa L.) farming. Turk. J. Fish. Aquat. Sci. 19, 885-891. doi: 10.4194/1303-2712v19_10_08 
USDA (2007). Nitrogen Efficiency and Management. Nutrient Management Technical Note No. 6. Washington DC: NRCS.

Wheatly, M. G. (1999). Calcium homeostasis in crustacea: the evolving role of branchial, renal, digestive and hypodermal epithelia. J. Exp. Zool. 283, 620-640. doi: 10.1002/(SICI)1097-010X

$\mathrm{Wu}, \mathrm{R}$. (1995). The environmental impact of marine fish culture: towards a sustainable future. Mar. Pollut. Bull. 31, 159-166. doi: 10.1016/0025-326X(95) 00100-2

Xia, S., Li, Y., Wang, W., Rajkumar, M., Kumaraguru Vasagam, K. P., and Wang, H. (2010). Influence of dietary protein levels on growth, digestibility, digestive enzyme activity and stress tolerance in white-leg shrimp, Litopenaeus vannamei (Boone, 1931), reared in high-density tank trials. Aquac. Res. 41, 1845-1854. doi: 10.1111/j.1365-2109.2010.02585.x

$\mathrm{Xu}$, W. J., Morris, T. C., and Samocha, T. M. (2016). Effects of C/N ratio on biofloc development, water quality, and performance of Litopenaeus vannamei juveniles in a biofloc-based, high-density, zero-exchange, outdoor tank system. Aquaculture 453, 169-175. doi: 10.1016/j.aquaculture.2015.11.021

$\mathrm{Xu}$, W. J., and Pan, L. Q. (2012). Effects of bioflocs on growth performance, digestive enzyme activity and body composition of juvenile Litopenaeus vannamei in zero-water exchange tanks manipulating $\mathrm{C} / \mathrm{N}$ ratio in feed. Aquaculture 35, 147-152. doi: 10.1016/j.aquaculture.2012.05.022

Xu, W. J., and Pan, L. Q. (2014). Evaluation of dietary protein level on selected parameters of immune and antioxidant systems, and growth performance of juvenile Litopenaeus vannamei reared in zero-water exchange biofloc-based culture tanks. Aquaculture 42, 181-188. doi: 10.1016/j.aquaculture.2014.02.003

Xu, W. J., Pan, L. Q., Zhao, D. H., and Huang, J. (2012). Preliminary investigation into the contribution of bioflocs on protein nutrition of Litopenaeus vannamei fed with different dietary protein levels in zero-water exchange culture tanks. Aquaculture 35, 147-153. doi: 10.1016/j.aquaculture.2012.04.003

Yang, J., Zhu, B., Ni, X., and He, Y. (2020). Ammonium/nitrate ratio affects the growth and glucosinolates content of pakchoi. Hortic. Bras. 38, 246-253. doi: 10.1590/s0102-053620200302

Yang, T., and Kim, H. J. (2019). Nutrient management regime affects water quality, crop growth, and nitrogen use efficiency of aquaponic systems. Sci. Hortic. 256:108619. doi: 10.1016/j.scienta.2019.108619

Yang, T., and Kim, H. J. (2020a). Characterizing nutrient composition and concentration in tomato-, basil-, and lettuce-based aquaponic and hydroponic systems. Water 12:1259. doi: 10.3390/W12051259

Yang, T., and Kim, H. J. (2020b). Effects of hydraulic loading rate on spatial and temporal water quality characteristics and crop growth and yield in aquaponic systems. Horticulturae 6:9. doi: 10.3390/horticulturae601 0009

Yun, H., Shahkar, E., Katya, K., Jang, I. K., Kyoung, K. S., and Bai, S. C. (2016). Effects of bioflocs on dietary protein requirement in juvenile whiteleg shrimp, Litopenaeus vannamei. Aquac. Res. 47, 3203-3214. doi: 10.1111/are.12772

Zanotto, F. P., and Wheatly, M. G. (1993). The effect of ambient pH on electrolyte regulation during the postmoult period in freshwater crayfish Procambarus clarkii. J. Exp. Biol. 178, 1-19. doi: 10.1242/jeb.178.1.1

Zanotto, F. P., and Wheatly, M. G. (1995). The effect of water $\mathrm{pH}$ on postmolt fluxes of calcium and associated electrolytes in the freshwater crayfish (Procambarus clarkii). Freshw. Crayfish 8, 437-450. doi: 10.5869/fc.1995.v8.437

Zhang, J., Lv, J., Dawuda, M. M., Xie, J., Yu, J., Li, J., et al. (2019). Appropriate ammonium-nitrate ratio improves nutrient acumulation and fruit quality in pepper (Capsicum annuum L.). Agronomy 9:683. doi: 10.3390/ agronomy9110683

Zhao, K., and Feng, L. (2001). Chinese Halophyte Resources, 1st Edn. Beijing: China Science Publishing \& Media Ltd.

Zhu, S., and Chen, S. (2001). Effects of organic carbon on nitrification rate in fixed film biofilters. Aquac. Eng. 25, 1-11. doi: 10.1016/S0144-8609(01)00071-1

Zhu, Y., Qi, B., Hao, Y., Liu, H., Sun, G., Chen, R., et al. (2021). Appropriate NH4+/NO3- ratio triggers plant growth and nutrient uptake of flowering Chinese cabbage by optimizing the $\mathrm{pH}$ value of nutrient solution. Front. Plant Sci. 12:656144. doi: 10.3389/fpls.2021.656144

Conflict of Interest: The authors declare that the research was conducted in the absence of any commercial or financial relationships that could be construed as a potential conflict of interest.

Publisher's Note: All claims expressed in this article are solely those of the authors and do not necessarily represent those of their affiliated organizations, or those of the publisher, the editors and the reviewers. Any product that may be evaluated in this article, or claim that may be made by its manufacturer, is not guaranteed or endorsed by the publisher.

Copyright (c) 2022 Chu and Brown. This is an open-access article distributed under the terms of the Creative Commons Attribution License (CC BY). The use, distribution or reproduction in other forums is permitted, provided the original author(s) and the copyright owner(s) are credited and that the original publication in this journal is cited, in accordance with accepted academic practice. No use, distribution or reproduction is permitted which does not comply with these terms. 